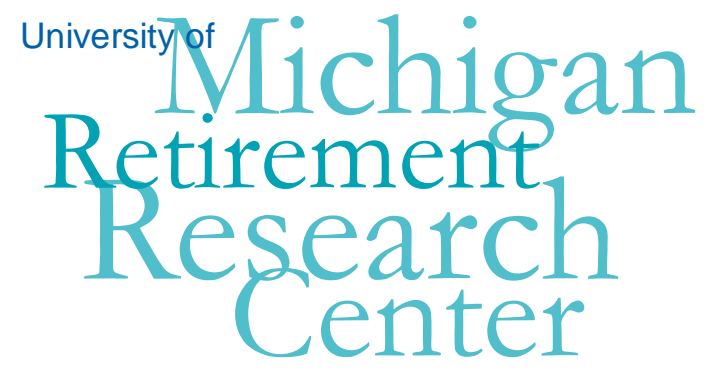

Working Paper

WP 2010-226

\title{
Financial Capability in the United States: Consumer Decision-Making and the Role of Social Security
}

\author{
Annamaria Lusardi
}

\begin{tabular}{|c|c|}
\hline $\mathrm{M}$ & $\mathrm{R}$ \\
\hline $\mathrm{R}$ & $\mathrm{C}$ \\
\hline
\end{tabular}

Project \#: UM10-22 


\title{
Financial Capability in the United States: Consumer Decision-Making and the Role of Social Security
}

\author{
Annamaria Lusardi \\ Dartmouth College and Financial Literacy Center
}

September 2010

\author{
Michigan Retirement Research Center \\ University of Michigan \\ P.O. Box 1248 \\ Ann Arbor, MI 48104 \\ http://www.mrrc.isr.umich.edu/
}

(734) 615-0422

\section{Acknowledgements}

This work was supported by a grant from the Social Security Administration through the Michigan Retirement Research Center (Grant \# 10-M-98362-5-01). The findings and conclusions expressed are solely those of the author and do not represent the views of the Social Security Administration, any agency of the Federal government, or the Michigan Retirement Research Center.

Regents of the University of Michigan

Julia Donovan Darrow, Ann Arbor; Laurence B. Deitch, Bingham Farms; Denise Ilitch, Bingham Farms; Olivia P. Maynard, Goodrich; Andrea Fischer Newman, Ann Arbor; Andrew C. Richner, Grosse Pointe Park; S. Martin Taylor, Gross Pointe Farms; Katherine E. White, Ann Arbor; Mary Sue Coleman, ex officio 


\title{
Financial Capability in the United States: Consumer Decision-Making and the Role of Social Security
}

\begin{abstract}
This paper analyzes new data from the 2009 National Financial Capability Study. This survey provides information to assess how American households make financial decisions, how they are faring under current economic conditions, and in what ways financial knowledge contributes to financial capability. In addition, it includes data about the information that the Social Security Administration (SSA) provides to consumers. The paper finds that the majority of individuals do not plan for retirement or make provisions against shocks. Debt management often results in sizable interest payments and fees and it is notable how many individuals have used high-cost methods of borrowing in the past five years. Levels of financial knowledge are strikingly low and many respondents do not possess knowledge of basic concepts. Social Security has taken steps to provide information about what individuals will expect to receive when they retire. The self-reported evidence provided in the survey shows that the information has been used by about a quarter of the population who acknowledge receiving the statement. Moreover, there are large differences among use in demographic groups and some of the more vulnerable populations, such as African-Americans, those hit by shocks, and single and separated individuals are more likely to use the statement.
\end{abstract}

\section{Authors’ Acknowledgements}

The research reported herein was conducted pursuant to a grant from the U.S. Social Security Administration (SSA) to the Michigan Retirement Research Center, funded as part of the Retirement Research Consortium. The author thanks Chris Bumcrot and Judy Lin for help with the data, Ben Rump for excellent research assistance, and Audrey Brown for comments and editorial support. Opinions and errors are solely those of the author. 


\section{RESEARCH QUESTION AND POLICY RELEVANCE}

This paper analyzes data from the 2009 National Financial Capability Survey, which the principal investigator helped design. This survey provides new and unique information to assess how American households make financial decisions, how they fare in current economic conditions, and in what ways financial knowledge contributes to financial capability. Moreover, several questions about the provision of information from the Social Security Administration (SSA) have been added to the survey, and it is possible to assess whether this information has consequences for behavior. The Social Security program provides more than half of the income for two-thirds of the elderly population, and represents 90 percent of income for 34 percent of the elderly population (Fast Facts \& Figures About Social Security, 2004), so information about expected Social Security benefits should be an important factor in most retirement decisions.

This research is informative for policy in several ways. First, the analysis indicates which groups are most prone to poor financial decision-making and whether greater financial literacy enhances financial capability. Second, it is possible to evaluate the effect of information about Social Security benefits on consumer behavior. Finally, findings from this research could be used to design financial education programs that are more effective in fostering financial capability.

\section{PREVIOUS RESEARCH}

Over the last decade, several researchers have started to explore whether individuals are well-equipped to make financial decisions. Bernheim $(1995,1998)$ was among the first to document that many U.S. consumers display low levels of financial literacy. Hilgert, Hogarth, and Beverly (2003) report that most Americans fail to understand basic financial concepts, 
particularly those relating to bonds, stocks, and mutual funds. This problem may persist for some time. The National Council on Economic Education's report (NCEE 2005) shows a widespread lack of knowledge regarding fundamental economic concepts among high school students, confirming similar findings by the Jump\$tart Coalition for Personal Financial Literacy (Mandell, 2008).

Low financial skill levels are not only a U.S. problem: The 2005 report on financial literacy by the Organisation for Economic Co-operation and Development (OECD) and Smith and Stewart (2008) document low levels of financial literacy in several countries. Similarly, the Survey of Health, Aging and Retirement in Europe (SHARE) shows that respondents score poorly on financial numeracy and literacy scales (Christelis, Jappelli, and Padula, 2010).

Lusardi and Mitchell’s (2006, 2008a) module on planning and financial literacy for the 2004 Health and Retirement Study (HRS) provides further evidence of financial illiteracy. They find that many older (50+) individuals cannot do simple interest-rate calculations, such as calculating how money would grow at an interest rate of $2 \%$, and do not know about the workings of inflation and risk diversification. Similar results are seen in a sample of early Baby Boomers (ages 51-56) and among young adults (23-27): most respondents display low numeracy and a very limited knowledge of the power of interest compounding (Lusardi and Mitchell, 2007a, 2008b; Lusardi, Mitchell, and Curto, 2010).

Financial literacy has been linked to saving behavior and portfolio choice. For example, the less financially literate are found to be less likely to plan for retirement (Lusardi and Mitchell, 2006, 2007b, 2008a), to accumulate wealth (Stango and Zinman, 2009), and to participate in the stock market (van Rooij, Lusardi, and Alessie, 2007; Kimball and Shumway, 2006). Moreover, less literate individuals are less likely to choose mutual funds with lower fees 
(Hastings and Tejeda-Ashton, 2008). There is evidence that financial literacy affects debt as well. Moore (2003) reports that respondents with lower levels of financial literacy are more likely to have costly mortgages. Similarly, Campbell (2006) shows that individuals with lower incomes and lower education levels—characteristics that are strongly related to financial literacy—are less likely to refinance their mortgages during a period of falling interest rates. Lusardi and Tufano (2009a) show that those with low literacy are more likely to engage in high-cost borrowing.

\section{RESEARCH DATA AND METHODOLOGY}

The National Financial Capability Study consists of three linked surveys: (1) the National Survey, a nationally projectable telephone survey of 1,488 American adults; (2) the State-byState Survey, a state-by-state online survey of approximately 25,000 American adults (roughly 500 per state, plus the District of Columbia); and (3) the Military Survey, an online survey of 800 military service members and spouses. This paper uses data from the National Survey, administered to respondents between May and July of 2009. The primary sample of 1,200 respondents was constructed to be representative of the general adult U.S. population. To ensure a sufficient number of respondents for the analysis, African-Americans, Hispanics, AsianAmericans, and adults with less than a high school education were oversampled. The total number of respondents in the sample was 1,488 . The data collection and design of the survey instruments was supported by FINRA Investor Education Foundation. ${ }^{1}$

It's worth noting that a handful of other countries have so far collected data on financial literacy/ financial capability. The United Kingdom was among the first to design a survey on

\footnotetext{
${ }^{1}$ More information about this survey is provided at: http://www.finrafoundation.org/resources/research/p120478 and in Lusardi (2010).
} 
financial capability, in 2005, and similar initiatives have been undertaken in New Zealand, Australia, Ireland, Canada, and the Netherlands (Atkinson, McKay, Kempson, and Collard, 2006). New Zealand is one of the few countries to have followed up with a second survey: a 2009 survey was designed to assess the changes in financial knowledge and behavior of New Zealanders over a three-year span.

The overarching research objectives of the U.S. financial capability survey were to benchmark key indicators of financial capability and evaluate how these indicators vary with underlying demographic, behavioral, attitudinal, and financial literacy characteristics. Financial capability cannot be judged simply by looking at one indicator. Rather, it covers several aspects of behavior. Consistent with the surveys that have been done in other countries, these behavior aspects include how people manage their resources, how they make financial decisions, the skill set they use in making such decisions, and the search and information elaboration that goes into those decisions.

While the survey data provide a richer set of information, this paper focuses on four main areas to assess Americans' financial capability:

(1) Making ends meet

(2) Planning ahead

(3) Choosing and managing financial products

(4) Financial literacy and self-assessed skills

The simple statistics reported below paint a picture of the current state of financial capability in the U.S. population and of who is less (or more) financially capable. ${ }^{2}$

\section{(1) Making ends meet}

\footnotetext{
${ }^{2}$ For a detailed discussion of financial capability, see Lusardi (2010).
} 
A key building block of financial capability is the ability to make ends meet, which can be measured by examining how people deal with everyday financial matters and the extent to which they balance monthly income and expenses to avoid overspending. The data indicate several signs of financial strain among American adults.

As reported in Table 1, almost half of Americans reported having trouble keeping up with monthly expenses and bills (with almost 14 percent of survey respondents stating it is very difficult to do so and 35 percent finding it somewhat difficult). Difficulty with making ends meet is particularly high among the young and those with low income (income less than $\$ 25,000$ ).

The recent economic crisis has hit individuals hard, hindering their ability to make ends meet. One-third of respondents to the survey stated they had experienced a large and unexpected drop in income during the past year. Workers earning less than \$25,000 a year and Hispanics appear to have been especially hard hit, with 41 percent and 43 percent, respectively, reporting a drop in income. Across all demographic groups, those who suffered large decreases in income were more likely to report having difficulties covering their expenses.

\section{(2) Planning ahead}

There are several life events that families need to plan for, such as retirement. And because the future is inherently uncertain, families also need to make provisions to buffer themselves against shocks. Being able to weather shocks not only contributes to financial stability at the micro level but also increases stability of the macro economy.

Rainy day funds

One important finding of the data is the lack of rainy day funds for a large part of the population. Only 49 percent of respondents have set aside emergency or rainy day funds that would cover expenses for 3 months in case of sickness, job loss, economic downturn, or other emergency 
(Table 1). Thus, many families would not be able to draw on personal financial resources if hit by a shock. And those without rainy day funds are more likely to be hit by shocks. While in the overall respondent population, 33 percent reported having experienced a large decrease in income in the past 12 months, among those without rainy day funds, the proportion is 40 percent. Thus, while some may not have an emergency fund because a shock depleted their buffer stock of savings, the economy is fragile to shocks.

These findings are consistent with the results from the Global Economic Crisis survey, a survey fielded between June and September of 2009 in thirteen countries including the United States by the survey research firm TNS Global. To assess Americans’ confidence in their ability to cope with a small financial shock, respondents were asked how confident they were that they could come up with $\$ 2,000$ if an unexpected need arose within the next month. As many as 46 percent of Americans stated they cannot or are not confident they could come up with $\$ 2,000$ in a month's time (Lusardi, Schneider, and Tufano, 2010). The widespread lack of modest buffer stocks of savings makes the current economy overly vulnerable to unexpected events.

Vulnerability to shocks is not only widespread in the population but it is particularly severe among some demographic groups. A small fraction of the young (age 18-29) and those with low income have emergency funds. However, income and age are not the sole predictors of having rainy day funds. Even those with income above $\$ 75,000$ and those who should be at the peak of wealth accumulation (age 45-59) do not always make provisions for shocks. Conversely, some low-income individuals and young adults do make provisions.

\section{Planning for retirement}

In addition to not preparing for unforeseen emergencies, people do not prepare for predictable events. Despite the changes in the pension landscape in the past twenty years and the 
increased individual responsibility for financial security after retirement, the majority of Americans have not done any retirement planning. Making decisions about how much to save in order to afford a comfortable retirement requires collecting information about several important variables (including Social Security and pension benefits) and doing some, even rudimentary, calculations. Yet, when asked whether they have ever tried to figure out how much they need to save for retirement, only 42 percent of respondents who are not retired said they had.

Lack of planning is high not only among young respondents, but also among older adults: only 51 percent of respondents who are 45-59 years old and not yet retired have tried to calculate how much they need to save for retirement. Thus, while the proportion of planners increases with age, even close to retirement only a little more than half of older individuals have attempted to calculate how much they need to save. Among low-income respondents, we see that retirement planning is low or even nonexistent. These findings are consistent with data on retirement planning from other surveys, such as the Health and Retirement Study and Retirement Confidence Survey. Those surveys as well document lack of retirement planning, even when retirement is not far away (Lusardi, 1999, 2009; Yakoboski and Dickemper, 1997).

\section{(3) Choosing and managing financial products}

There is a lot of information in the survey on how individuals choose and manage financial products, from how people manage their liquidity, how they borrow, and their exposure to financial market risks. I will focus on one specific behavior in the paper, which is high-cost borrowing. One of the striking results of this survey is the sizable share of Americans who engage in alternative forms of borrowing, such as taking out an auto-title loan, a "payday" loan, getting an advance on tax refunds, using pawn shops, or using a rent-to-own store. All of these 
borrowing methods usually charge high interest rates; much higher than are charged by banks or by credit card companies. As described in Table 1, while a small fraction of the population has used each method of borrowing, as many as 23 percent have used one of these methods in the last five years. The use of these alternative methods of borrowing is also highly correlated: those who have used pawn shops are more likely to have used an advance on tax refunds or taken out a payday loan and vice versa. Most importantly, these alternative methods of borrowing are disproportionately—though not exclusively—used by those who are unbanked. Thus, lack of a bank account is likely to result in the utilization of high-cost borrowing. Many of the users of these alternative methods also do not have credit cards. Lack of formal ways of borrowing often translates into heavier use of high-cost borrowing.

The high interest rates and fee payments that high-cost borrowing generates are paid by the most frequent users of these methods, who are disproportionately the young, those with low income, those without a high school education, and African-Americans and Hispanics.

\section{(4) Financial literacy and self-assessed skills}

In order to make financial decisions, individuals have to be equipped with some skills that allow them to understand and process the information that is often a required input for decisions. When asked to assess their financial knowledge, most respondents give themselves high scores. On a scale from 1 to 7 , where 1 indicates very low and 7 very high financial knowledge, 38 percent of respondents rate their financial knowledge with scores of 6 or 7 . These findings are consistent with the results of other surveys, such as the TNS Survey and the American Life Panel. When asked to assess their financial knowledge, individuals gave themselves high rankings (Lusardi and Tufano, 2009a; Lusardi and Mitchell, 2009). 
To evaluate the actual level of financial knowledge, respondents were exposed to a battery of questions covering fundamental concepts of economics and finance, expressed as they would be in everyday transactions, such as simple calculations about interest rates and inflation, the workings of risk diversification, the relationship between bond prices and interest rates, and the relationship between interest payments and maturity in mortgages. ${ }^{3}$

While the correct response to individual questions is sometimes high, less than half of respondents answered two questions about interest rates and inflation correctly and less than onethird answered those questions and a question about risk diversification correctly (Table 2a). Less than 10 percent of respondents are able to answer all questions correctly (Table $2 \mathrm{~b}$ ). This is consistent with the findings documented in a variety of other studies using the same questions or a sub-set of the questions used in this survey (Lusardi and Mitchell, 2006, 2009) and highlight not just that people lack financial literacy but also how little they know about rather basic concepts in economics and finance.

Not only is financial illiteracy widespread in the population but it is particularly severe among some groups. As shown in Figure 1, financial literacy is low among women, those with low education, and among African-Americans and Hispanics, as reported in previous work as well (Lusardi and Mitchell, 2006, 2007a, 2009; Lusardi, Mitchell, and Curto, 2009, 2010; Lusardi and Tufano, 2009a, b).

One of the important questions is not only how financial capability measures are related to each other but also what can be done to improve financial capability. In the second part of the paper, I discuss initiatives that SSA has undertaken to improve financial decision-making and retirement planning. In the next section, I examine the relationship between financial literacy and other measures of financial capability.

\footnotetext{
${ }^{3}$ For the exact wording of the questions, see the data appendix.
} 


\section{DOES FINANCIAL LITERACY AFFECT FINANCIAL DECISION-MAKING?}

As I have argued in previous work, financial literacy is an essential tool for informed consumer choice (Lusardi (2008)). The Financial Capability Study data allow researchers to link financial literacy to financial behavior, such as whether people manage their money so that they are able to pay their bills, whether they put money aside for a rainy day, and whether they engage in highcost borrowing. There has already been a lot of research assessing the link between financial literacy and retirement planning (Lusardi and Mitchell, 2006, 2007a, 2008a, 2009). The use of new data will determine whether this finding is robust and whether it holds in different economic conditions, such as at the height of a financial crisis.

To perform the empirical work, I restrict the sample to respondents who are older than 25 and younger than 65 to exclude students or people still living at home and those who are in the decumulation phase of their life cycle. I also account for a set of variables that can proxy for preferences, lifetime income, and shocks. The list of demographic characteristics includes age and age squared, to capture the hump-shaped profile of financial decisions, and sex, race, and marital status. Moreover, I add dummies for income, education, and retirement status to proxy for lifetime income. I add a dummy for the self-employed as they are very different from the rest of the population both in terms of lifetime income and wealth (Hurst, Lusardi, Kennickell and Torralba, 2010). To proxy for shocks and constraints in the household, I add a dummy for having a large and unexpected drop in income during the past year, for whether the respondent is unemployed, and dummies for the number of children who are financially dependent on the respondent.

I use two measures of financial literacy. The first measure makes use of the answers to the five questions in the survey, which can be divided into basic and advanced financial literacy. 
The dummy for basic literacy is equal to 1 if the respondent correctly answers either the questions about interest rates, the question about inflation, or the question about mortgages. These are simple questions that assess basic financial knowledge and are answered correctly by a larger percentage of respondents. The dummy for advanced literacy is equal to 1 if the respondent correctly answers the question about risk diversification or the question about bond pricing. These are questions aiming to capture knowledge of more sophisticated concepts, and correct answers classify respondents as having a higher level of financial knowledge. I also use information about self-assessed financial knowledge, as this should also affect financial decisionmaking.

Table 3 reports some of the simple univariate statistics describing the relationship between financial literacy and financial behavior. For all measures, higher levels of financial literacy, measured using subjective and objective methods, are correlated with more planning (both for retirement and for emergencies), lower use of high-cost borrowing methods, and less difficulty in paying bills. I examine next whether this positive relationship holds true when we account for the large set of demographic characteristics that were mentioned above.

As reported in Table 4, financial literacy, in particular advanced literacy, continues to be related to financial behavior even after accounting for a large set of controls, including income and education. Specifically, those who display advanced literacy, are more likely to plan for retirement, are less likely to have problems paying bills, and less likely to use high-cost methods of borrowing. Similarly, those who report high levels of self-assessed literacy are also more likely to plan for retirement and to plan for emergencies, while they are less likely to experience problems paying bills or engage in high-cost borrowing (Table 5). 
These findings are consistent with the evidence provided in other papers. For example, Lusardi and Mitchell (2006, 2008a, 2009) use data from the Health and Retirement Study and the American Life Panel and show that higher levels of financial knowledge lead respondents to plan more for retirement. Given that the questions used in the Financial Capability Survey are mostly a subset of the questions used in those other papers, the relationship between financial literacy and retirement planning seems a robust finding. Moreover, while one can argue that the causality goes in a different direction, Lusardi and Mitchell (2009) show that it is financial literacy that affects retirement planning and not the other way around. Lusardi and Tufano (2009a) have also shown the relationship between financial literacy and debt, a finding which is confirmed in this work. The higher cost of debt that low literacy individuals face may be one reason why financial literacy is found to be related to wealth accumulation (Lusardi and Mitchell, 2006; Stango and Zinman, 2009). Notwithstanding the importance of many variables, those who have higher financial literacy are less likely to have problems with bills, perhaps because they are better planners.

Several other controls in the regressions merit consideration. High education is another important determinant of the quality of financial decision-making and it is important to see that financial literacy still has an effect, above and beyond the effect of education. Moreover, shocks to income have been an important factor in explaining individuals' financial behavior: those who have been hit by large shocks are more likely to experience difficulty paying bills and are more likely to borrow at high costs. Those with many children are also likely to have more difficulties with both debt and paying bills. There are also difference across race, with African-Americans less likely to have emergency funds and more likely to use high-cost methods of borrowing and Hispanics being less likely to use high-cost methods of borrowing. 


\section{THE ROLE OF SOCIAL SECURITY}

Beyond improving individuals' financial literacy levels, there are other ways to enhance financial capability. Since 1995, the Social Security Administration has issued statements notifying individuals about their estimated Social Security benefits upon retirement, a very important piece of information that should help workers in their decision-making. Research by Mastrobuoni (2006) suggests that these statements improve workers' knowledge about their expected benefits. However, the effect of the Social Security statement on behavior is mixed and, overall, inconclusive.

The Financial Capability Survey provides a direct way to test whether individuals are affected by the information provided by SSA. The survey contains the following three questions:

4. In the past 12 months, have you received a statement from the Social Security Administration that tells you how much money you can expect to receive from Social Security when you retire?

1. Yes; 2. No; 3. Don’t Know; 4. Refuse to answer.

5. [If received statement $(\mathrm{C} 12=1)$ ] Have you used the information to decide or adjust your decision about when to stop working?

1. Yes; 2. No; 3. Don't Know; 4. Refuse to answer.

6. [If received statement $(\mathrm{C} 12=1)$ ] Have you used the information to decide or adjust your decision about when to claim your Social Security benefits?

1. Yes; 2. No; 3. Don’t Know; 4. Refuse to answer.

The role of Social Security cannot be understated. As illustrated in the chart below, current retirees interviewed in the survey indicated they rely primarily on Social Security for their living expenses, while a much lower proportion rely on their accumulated savings and retirement accounts.

\begin{tabular}{|l|c|}
\hline \multicolumn{2}{|c|}{ Which of the following are you [retired respondents] using for living expenses? } \\
\hline Social Security retirement payments & $81 \%$ \\
\hline Pension plan payments & $63 \%$ \\
\hline Withdrawals from savings, investments or retirement accounts & $26 \%$ \\
\hline
\end{tabular}




\begin{tabular}{|l|c|}
\hline Dividends or interest income from savings, investments or retirement accounts & $23 \%$ \\
\hline Salary, wages or self-employment income & $17 \%$ \\
\hline Rental income or proceeds from a sale of real estate & $12 \%$ \\
\hline Payments from a reverse mortgage & $1 \%$ \\
\hline Financial support from family & $3 \%$ \\
\hline
\end{tabular}

As Table 6 indicated, about 65 percent of respondents indicated receiving a statement from Social Security, but there are large differences among income groups: only 37 percent of those with income below $\$ 25,000$ acknowledge receiving the statement, versus 86 percent of those with income above $\$ 75,000$. However, the statement seems to play a role in affecting retirement decisions and when to claim Social Security benefits: as many as 25 percent of those who acknowledge receiving statements stated they have used them in their decision about when to claim Social Security benefits. This is a critically important decision that can have vast implications on financial well-being after retirement. Moreover, 21 percent stated they have used the statement to make their decision about when to stop working. Taken at face value, these are remarkable figures; few financial education programs can claim to have an effect on such a large sample of a target group. We do not know in which direction the effect of the statement worked and whether and how much it was a critical factor. Moreover, it could be that it is those who recalled receiving the statement who are more likely to report an effect, so the statistics may overstate the impact on the population who was sent the statement. Nevertheless, these statistics are encouraging and deserve further investigation.

As illustrated in Table 6, the effects of the statement differ both across age and income groups. The lower income groups are more likely to use the statement for their decision. As expected, the use of the statement becomes much more pronounced with increasing respondent 
age. There are also very large differences in the use of the statement among racial and ethnic groups: African-American respondents are disproportionately more likely to use the statement.

To further investigate the heterogeneity in the use of the statement and which variables remain significant once I account for both income and age, I consider an extended set of demographics, like the ones used in the specification about financial decisions (Table 7). Interestingly, there is an effect of financial literacy: those with higher self-reported literacy are more likely to use the statement to decide when to withdraw Social Security benefits and when to retire. This finding suggests that while, statements are important, perhaps respondents need to still have financial literacy and/or confidence in their literacy to be able to make use of that information. Even after accounting for a large set of demographic characteristics and income, African-Americans are those more likely to use the statement to make decisions about retirement and when to claim Social Security benefits. Marital status also plays a role: those who are single or separated from a spouse are more likely to use the statement for their decision-making. Since these are individuals who may face more difficult economic circumstances, we might conclude that the statement seems to have an impact on some vulnerable groups. Those with more children are less likely to use the statement in their decision-making, perhaps because their choices are more constrained. Those hit by a large decrease in income are more likely to use the statement to decide when to withdraw Social Security benefits: given the severity of the financial crisis, it seems that the statement has been of use to those who have faced economic difficulties. Age is again an important factor and the use of the statement is heavily dependent on age. To consider the fact that the statement may be more relevant for those not very far away from retirement, I have also restricted the sample to those older than 50 (Table 8). One notable result is that 
African-Americans are still those more likely to use the statement for their financial decisions. There is again an effect of age; the statement is more likely to be used close to the retirement age.

\section{DISCUSSION}

The findings from the National Survey paint a troubling picture of the current state of financial capability in the U.S. adult population. The majority of individuals do not plan for retirement or make provisions against shocks. Debt management often results in sizable interest payments and fees and it is notable how many individuals have used high-cost methods of borrowing in the past five years. Levels of financial knowledge are strikingly low and many respondents do not possess the knowledge of basic concepts.

The reason lack of planning is important is that many studies have shown that planning is a very strong predictor for wealth: those who do not plan get close to retirement with half the amount of wealth of those who have done some planning (Lusardi, 1999, 2009; Lusardi and Beeler, 2007; Lusardi and Mitchell, 2007a,b, 2009; Ameriks, Caplin, and Leahy, 2003). And, the direction of causality runs from planning to wealth and not the other way around. While one could argue that it is wealth that causes more planning, in fact Lusardi and Mitchell (2007a) show that exogenous shocks to wealth did not generate more planning, while planning ends up generating higher amounts of wealth. Moreover, the "cost of ignorance" can be high. Lusardi and Tufano (2009a) trace some of the behavior related to debt back to debt illiteracy, i.e., lack of knowledge about the workings of credit cards and the principles of interest compounding.

It is also worrisome that behaviors leading to high interest payments or fees are most prevalent among those with low income and low education, i.e., those who can least afford high interest payments and fees. It is possible that these behaviors will put greater strain on existing 
social safety nets. When people make poor financial decisions, the cost of those decisions can be passed on to all Americans through higher prices for financial products and the diversion of economic resources. Lack of financial capability matters not only for the individual but also for society as a whole.

Social Security has taken steps to provide information about what individuals will expect to receive when they retire. The self-reported evidence provided in the survey shows that the information has been used by about a quarter of the population who acknowledge receiving the statement. Moreover, there are large differences among use in demographic groups and some of the more vulnerable populations, such as African-Americans, those hit by shocks, and single and separated individuals are more likely to use the statement. Financial literacy is also a predictor for using the statement, supporting evidence offered in the first part of the paper that one needs basic knowledge to make sound financial decisions. 


\section{Data Appendix}

In consultation with the U.S. Department of the Treasury and the President's Advisory Council on Financial Literacy, the FINRA Investor Education Foundation commissioned a national study of the financial capability of American adults. The overarching research objectives were to benchmark key indicators of financial capability and evaluate how these indicators vary with underlying demographic, behavioral, attitudinal, and financial literacy characteristics.

The National Financial Capability Study consists of three linked surveys:

- National Survey: A nationally-projectable telephone survey of 1,488 American adults

- State-By-State Survey: A state-by-state online survey of approximately 25,000 American adults (roughly 500 per state, plus the District of Columbia)

- Military Survey: An online survey of 800 military service members and spouses

The survey instruments were designed by a multi-disciplinary team including Annamaria Lusardi of Dartmouth College, Applied Research \& Consulting LLC (ARC), the FINRA Investor Education Foundation and the Office of Financial Education of the U.S. Treasury Department. Additional input was provided by Craig Copeland of the Employee Benefit Research Institute (EBRI), the American Institute of Certified Public Accountants (AICPA) and Robert Willis of the University of Michigan, among others.

This report outlines the findings of the National Survey, administered to respondents between May and July of 2009. The primary sample of 1,200 respondents was constructed to be representative of the general adult U.S. population. To ensure a sufficient number of respondents for the analysis, African-Americans, Hispanics, Asian Americans and adults with less than a high school education were oversampled. The total number of respondents in the sample was 1,488. The results of the State-by-State Survey and the Military Survey will be released in late 2010.

\section{Questions to measure financial literacy}

1) Suppose you had $\$ 100$ in a savings account and the interest rate was $2 \%$ per year. After 5 years, how much do you think you would have in the account if you left the money to grow? More than $\$ 102$

Exactly $\$ 102$

Less than $\$ 102$

Do not know

Refuse to answer

2) Imagine that the interest rate on your savings account was $1 \%$ per year and inflation was $2 \%$ per year. After 1 year, how much would you be able to buy with the money in this account? More than today Exactly the same

Less than today

Do not know 
Refuse to answer

3) If interest rates rise, what will typically happen to bond prices?

They will rise

They will fall

They will stay the same

There is no relationship between bond prices and the interest rates

Do not know

Refuse to answer

4) Please tell me whether this statement is true or false. A 15-year mortgage typically requires higher monthly payments than a 30-year mortgage, but the total interest paid over the life of the loan will be less.

True

False

Do not know

Refuse to answer

5) Please tell me whether this statement is true or false. Buying a single company's stock usually provides a safer return than a stock mutual fund.

True

False

Do not know

Refuse to answer 


\section{REFERENCES}

Ameriks, John, Andrew Caplin, and John Leahy (2003), "Wealth accumulation and the propensity to plan." Quarterly Journal of Economics 68, 10071047.

Atkinson, Adele, Stephen McKay, Elaine Kempson, and Sharon Collard (2006), "Levels of Financial Capability in the UK: Results of a baseline survey," Financial Services Authority.

Bernheim, Douglas (1995), "Do households appreciate their financial vulnerabilities? An analysis of actions, perceptions, and public policy,” in Tax Policy and Economic Growth, American Council for Capital Formation, Washington, DC, pp. 1-30.

Bernheim, Douglas (1998), "Financial illiteracy, education and retirement saving,” in O. Mitchell and S. Schieber (eds.), Living with Defined Contribution Pensions, University of Pennsylvania Press, Philadelphia, pp. 38-68.

Campbell, John (2006), “Household Finance,” Journal of Finance 61, pp.15531604.

Christelis, Dimitris, Tullio Jappelli, and Mario Padula (2010), “Cognitive abilities and portfolio choice,” European Economic Review 54, pp. 18-38.

Fast Facts \& Figures About Social Security (2004), Technical Report, Social Security Administration, August.

Hastings, Justine, and Lydia Tejeda-Ashton (2008), "Financial Literacy, Information, and Demand Elasticity: Survey and Experimental Evidence from Mexico,” NBER Working Paper n. 14538.

Hilgert, Marianne, Jeanne Hogarth, and Sondra Beverly (2003), “Household Financial Management: The Connection between Knowledge and Behavior,” Federal Reserve Bulletin, 309-32.

Hurst, Erik, Annamaria Lusardi, Arthur Kennickell, and Francisco Torralba (2010), "The Importance of Business Owners in Assessing the Size of Precautionary Savings,” Review of Economics and Statistics 92, pp. 6169.

Kimball, Miles, and Tyler Shumway (2006), "Investor Sophistication and the Participation, Home Bias, Diversification, and Employer Stock Puzzle,” mimeo, University of Michigan.

Lusardi, Annamaria (1999), “Information, Expectations, and Savings for Retirement,” in Henry Aaron (ed.), Behavioral Dimensions of Retirement Economics, Washington, D.C.: Brookings Institution Press and Russell Sage Foundation, pp. 81-115. 
Lusardi, Annamaria (2008), "Financial Literacy: An Essential Tool for Informed Consumer Choice?” Working Paper, Joint Center for Housing Studies, Harvard University.

Lusardi, Annamaria, (2009), "U.S. Household Savings Behavior: The Role of Financial Literacy, Information and Financial Education Programs," in C. Foote, L Goette, and S. Meier (eds), Policymaking Insights from Behavioral Economics, Federal Reserve Bank of Boston, pp. 109-149.

Lusardi, Annamaria (2010), “Americans’ Financial Capability,” mimeo, Dartmouth College.

Lusardi, Annamaria and Jason Beeler (2007), "Saving Between Cohorts: The Role of Planning,” in B. Madrian, O. Mitchell, and B. Soldo (eds.), Redefining Retirement: How Will Boomers Fare? Oxford University Press, Oxford, 2007, pp. 271-295.

Lusardi, Annamaria, and Olivia S. Mitchell (2006), "Financial Literacy and Planning: Implications for Retirement Wellbeing," MRRC Working Paper n. 2006-144.

Lusardi, Annamaria, and Olivia S. Mitchell (2007a), "Baby Boomer Retirement Security: The Role of Planning, Financial Literacy, and Housing Wealth," Journal of Monetary Economics 54, pp. 205-224.

Lusardi, Annamaria, and Olivia Mitchell (2007b), "Financial Literacy and Retirement Preparedness: Evidence and Implications for Financial Education,” Business Economics, January 2007, pp. 35-44.

Lusardi, Annamaria, and Olivia Mitchell (2008a), "Planning and Financial Literacy. How Do Women Fare?” American Economic Review, 98(2), pp. 413-417.

Lusardi, Annamaria, and Olivia Mitchell (2008b), "How Much Do People Know About Economics and Finance? Financial Illiteracy and the Importance of Financial Education,” Policy Brief n. 5, MRRC, March 2008.

Lusardi, Annamaria, and Olivia Mitchell (2009), "How Ordinary Consumers Make Complex Economic Decisions: Financial Literacy and Retirement Readiness," NBER Working Paper n. 15350.

Lusardi, Annamaria, Olivia Mitchell and Vilsa Curto (2009), "Financial Literacy and Financial Sophistication Among Older Americans,” NBER Working Paper n. 15469.

Lusardi, Annamaria, Olivia Mitchell, and Vilsa Curto (2010), "Financial Literacy Among the Young,” Journal of Consumer Affairs, 44(2), pp 358-380.

Lusardi, Annamaria, and Peter Tufano (2009a), "Debt Literacy, Financial Experiences, and Overindebtedness,” NBER Working Paper n. 14808.

Lusardi, Annamaria, and Peter Tufano (2009b), "Teach Workers about the Peril of Debt,” Harvard Business Review, November, pp. 22-24. 
Lusardi, Annamaria, Daniel Schneider, and Peter Tufano (2010), "Households@Risk: A Cross-Country Study of Household Financial Risk,” mimeo, Harvard Business School.

Mandell, Lewis (2008), "Financial Education in High School," in Annamaria Lusardi (ed.), Overcoming the Saving Slump: How to Increase the Effectiveness of Financial Education and Saving Programs, Chicago: University of Chicago Press, pp. 257-279.

Mastrobuoni, Giovanni (2006), "Do Better-Informed Workers Make Better Retirement Choices? A Test Based on the Social Security Statement," Working Paper, Collegio Carlo Alberto, Turin, Italy.

Moore, Danna (2003), "Survey of Financial Literacy in Washington State: Knowledge, Behavior, Attitudes, and Experiences,” Technical Report n. 03-39, Social and Economic Sciences Research Center, Washington State University.

National Council on Economic Education (NCEE) (2005), "What American teens and adults know about economics," Washington, D.C.

Organization for Economic Co-operation and Development (2005), Improving Financial Literacy: Analysis of Issues and Policies, Paris, France.

Stango, Victor, and Jonathan Zinman (2009), "Exponential Growth Bias and Household Finance,” Journal of Finance 64, pp. 2807-2849.

Smith, Barbara, and Fiona Stewart (2008), "Learning from the Experience of OECD Countries: Lessons for Policy, Programs and Evaluations,” in Annamaria Lusardi (ed.), Overcoming the Saving Slump: How to Increase the Effectiveness of Financial Education and Saving Programs, Chicago: University of Chicago Press, pp. 345-367.

van Rooij, Maarten, Annamaria Lusardi, and Rob Alessie (2007), "Financial Literacy and Stock Market Participation,” MRRC Working Paper n. 2007162.

Yakoboski, Paul and Jennifer Dickemper (1997), "Increased Saving but Little Planning: Results of the 1997 Retirement Confidence Survey,” EBRI Issue Brief, 191. 


\begin{tabular}{|c|c|c|c|c|c|c|c|c|}
\hline \multicolumn{9}{|c|}{ TABLE 1: Financial capability by demographics } \\
\hline & & & & & & & Income & \\
\hline & $\underline{\text { Total }}$ & $18-24$ & $25-45$ & $46-65$ & $66+$ & $<\$ 25 \mathrm{~K}$ & $\begin{array}{l}\$ 25- \\
75 \mathrm{~K}\end{array}$ & $>\$ 75 \mathrm{~K}$ \\
\hline \multirow[b]{2}{*}{$\begin{array}{c}\text { Difficulty } \\
\text { paying bills }\end{array}$} & & \multicolumn{4}{|c|}{ Panel A } & & & \\
\hline & $49 \%$ & $60 \%$ & $51 \%$ & $48 \%$ & $37 \%$ & $71 \%$ & $47 \%$ & $21 \%$ \\
\hline \multirow[b]{2}{*}{$\begin{array}{l}\text { Have rainy day } \\
\text { funds }\end{array}$} & & \multicolumn{4}{|c|}{$\underline{\underline{\text { Panel B }}}$} & & & \\
\hline & $49 \%$ & $30 \%$ & $46 \%$ & $54 \%$ & $63 \%$ & $26 \%$ & $53 \%$ & $75 \%$ \\
\hline \multirow[b]{2}{*}{$\begin{array}{l}\text { Planned for } \\
\text { retirement }\end{array}$} & & \multicolumn{4}{|c|}{$\underline{\text { Panel C }}$} & & & \\
\hline & $44 \%$ & $19 \%$ & $43 \%$ & $53 \%$ & $46 \%$ & $22 \%$ & $47 \%$ & $67 \%$ \\
\hline \multirow[b]{2}{*}{$\begin{array}{l}\text { Used high-cost } \\
\text { borrowing }\end{array}$} & & \multicolumn{4}{|c|}{ Panel D } & & & \\
\hline & $23 \%$ & $31 \%$ & $32 \%$ & $17 \%$ & $9 \%$ & $31 \%$ & $21 \%$ & $16 \%$ \\
\hline $\begin{array}{l}\text { Note: This table re } \\
\text { day fund, have plan } \\
\text { using survey weigh }\end{array}$ & the & & espc & who & $\overline{\operatorname{dif}}$ & y payi & $\mathrm{ls}, \mathrm{h}$ & rainy \\
\hline
\end{tabular}




\begin{tabular}{|c|c|c|c|}
\hline \multicolumn{4}{|c|}{ TABLE 2a: Financial literacy } \\
\hline & Correct & Incorrect & $\begin{array}{l}\text { Don't } \\
\text { Know }\end{array}$ \\
\hline Interest rate question & $65 \%$ & $21 \%$ & $13 \%$ \\
\hline Inflation question & $64 \%$ & $20 \%$ & $14 \%$ \\
\hline Bond price question & $21 \%$ & $44 \%$ & $34 \%$ \\
\hline Mortgage question & $70 \%$ & $16 \%$ & $12 \%$ \\
\hline Risk question & $52 \%$ & $13 \%$ & $34 \%$ \\
\hline \multicolumn{4}{|c|}{$\begin{array}{l}\text { Note: This table reports the proportion of respondents who answered } \\
\text { each of the five financial literacy questions correctly, incorrectly and } \\
\text { with "do not know.” All figures are weighted using survey weights. }\end{array}$} \\
\hline
\end{tabular}

\begin{tabular}{|c|c|c|}
\hline \multicolumn{2}{|c|}{ TABLE 2b: Financial literacy } \\
\hline \hline $\begin{array}{c}\text { Either interest, inflation, or } \\
\text { mortgage question correct }\end{array}$ & $\begin{array}{c}\text { Either bond price or risk } \\
\text { question correct }\end{array}$ & All questions correct \\
\hline $91 \%$ & $57 \%$ & $10 \%$ \\
\hline \hline $\begin{array}{l}\text { Note: This table reports the proportion of respondents who were able to answer at least one of the } \\
\text { interest rate, inflation, or mortgage questions correctly; the proportion of respondents who were able to } \\
\text { answer at least one of the bond pricing or risk questions correctly; and the proportion of respondents } \\
\text { who answered all five questions correctly, respectively. All figures are weighted using survey weights. }\end{array}$ \\
\hline
\end{tabular}




\begin{tabular}{|c|c|c|c|c|c|}
\hline \multicolumn{6}{|c|}{ TABLE 3: Financial literacy and financial capability } \\
\hline & & $\begin{array}{l}\text { Retirement } \\
\text { Planning }\end{array}$ & $\begin{array}{l}\text { Rainy Day } \\
\text { Fund }\end{array}$ & $\begin{array}{l}\text { Difficulty } \\
\text { with Bills }\end{array}$ & $\begin{array}{l}\text { High-Cost } \\
\text { Borrowing }\end{array}$ \\
\hline \multirow{2}{*}{$\underline{\text { Basic literacy }}$} & No & $17 \%$ & $40 \%$ & $53 \%$ & $24 \%$ \\
\hline & Yes & $46 \%$ & $50 \%$ & $47 \%$ & $23 \%$ \\
\hline \multirow{2}{*}{$\underline{\text { High literacy }}$} & No & $30 \%$ & $40 \%$ & $59 \%$ & $29 \%$ \\
\hline & Yes & $53 \%$ & $56 \%$ & $41 \%$ & $19 \%$ \\
\hline \multirow{2}{*}{$\frac{\text { Low self-reported }}{\underline{\text { literacy }}}$} & No & $43 \%$ & $48 \%$ & $50 \%$ & $24 \%$ \\
\hline & Yes & $44 \%$ & $58 \%$ & $44 \%$ & $19 \%$ \\
\hline \multirow{2}{*}{$\frac{\text { High self-reported }}{\underline{\text { literacy }}}$} & No & $37 \%$ & $41 \%$ & $56 \%$ & $26 \%$ \\
\hline & Yes & $54 \%$ & $63 \%$ & $37 \%$ & $20 \%$ \\
\hline \multicolumn{6}{|c|}{$\begin{array}{l}\text { Note: This table reports the proportion of respondents across the four measures of financial capability } \\
\text { described in Table } 1 \text { above, broken down by financial literacy levels. "Basic literacy" is defined as having } \\
\text { answered at least one of the interest rate, inflation or mortgage questions correctly. "High literacy" is } \\
\text { defined as having answered at last one of the bond pricing or risk questions correctly. "Low self-reported } \\
\text { literacy" corresponds to a response of } 1-5 \text { on a seven-point self-assessment and "High self-reported } \\
\text { literacy" corresponds to responses of } 6 \text { and } 7 \text {. All figures are weighted using survey weight. }\end{array}$} \\
\hline
\end{tabular}




\begin{tabular}{|c|c|c|c|c|}
\hline \multicolumn{5}{|c|}{ TABLE 4: Financial capability and financial literacy (ages 25-65) } \\
\hline Variables & $\begin{array}{c}\text { Retirement } \\
\text { planning }\end{array}$ & Emergency fund & $\begin{array}{l}\text { Having difficulty } \\
\text { with bills }\end{array}$ & $\begin{array}{c}\text { Using high-cost } \\
\text { borrowing }\end{array}$ \\
\hline basic literacy & 0.0908 & -0.0296 & 0.0492 & -0.00461 \\
\hline & $(0.0584)$ & $(0.0579)$ & $(0.0557)$ & $(0.0534)$ \\
\hline high literacy & $0.0822 * *$ & 0.0364 & $-0.0674 * *$ & $-0.0563 *$ \\
\hline & $(0.0319)$ & $(0.0317)$ & $(0.0304)$ & $(0.0292)$ \\
\hline age & 0.00587 & 0.00107 & 0.00329 & -0.00782 \\
\hline & $(0.0117)$ & $(0.0116)$ & $(0.0111)$ & $(0.0107)$ \\
\hline age squared & $-2.67 e-05$ & $3.24 \mathrm{e}-05$ & $-2.17 e-05$ & $1.05 e-05$ \\
\hline & $(0.000133)$ & $(0.000132)$ & $(0.000127)$ & $(0.000122)$ \\
\hline female & -0.0173 & -0.0298 & 0.0195 & 0.0173 \\
\hline & $(0.0289)$ & $(0.0286)$ & $(0.0275)$ & $(0.0264)$ \\
\hline African-American & 0.0144 & $-0.130 * * *$ & 0.0679 & $0.0868 * *$ \\
\hline & $(0.0477)$ & $(0.0473)$ & $(0.0455)$ & $(0.0436)$ \\
\hline Hispanic & -0.0484 & -0.0342 & -0.0380 & $-0.101 * *$ \\
\hline & $(0.0468)$ & $(0.0464)$ & $(0.0446)$ & $(0.0428)$ \\
\hline Asian & $-0.145^{*}$ & 0.0346 & -0.0588 & -0.0928 \\
\hline & $(0.0740)$ & $(0.0734)$ & $(0.0706)$ & $(0.0677)$ \\
\hline Other race & 0.0866 & -0.0640 & 0.0311 & -0.0435 \\
\hline & $(0.104)$ & $(0.103)$ & $(0.0988)$ & $(0.0948)$ \\
\hline high school & 0.0465 & 0.0676 & -0.0307 & $-0.115^{* *}$ \\
\hline & $(0.0532)$ & $(0.0528)$ & $(0.0507)$ & $(0.0487)$ \\
\hline some college & $0.111 * *$ & 0.0632 & -0.0233 & -0.0675 \\
\hline & $(0.0555)$ & $(0.0551)$ & $(0.0530)$ & $(0.0508)$ \\
\hline college & $0.206 * * *$ & $0.151 * *$ & -0.0669 & $-0.142 * * *$ \\
\hline & $(0.0592)$ & $(0.0587)$ & $(0.0564)$ & $(0.0542)$ \\
\hline post graduate & $0.216 * * *$ & $0.208 * * *$ & -0.0831 & $-0.158 * *$ \\
\hline & $(0.0686)$ & $(0.0681)$ & $(0.0654)$ & $(0.0628)$ \\
\hline income $\$ 15-25 \mathrm{k}$ & 0.0711 & 0.0326 & 0.0437 & $0.0985^{*}$ \\
\hline & $(0.0602)$ & $(0.0597)$ & $(0.0574)$ & $(0.0551)$ \\
\hline income $\$ 25-35 k$ & 0.0885 & $0.117^{*}$ & $-0.145 * *$ & 0.0300 \\
\hline & $(0.0660)$ & $(0.0654)$ & $(0.0629)$ & $(0.0604)$ \\
\hline income $\$ 35-50 k$ & $0.208^{* * *}$ & $0.276 * * *$ & $-0.215 * * *$ & -0.0566 \\
\hline & $(0.0604)$ & $(0.0599)$ & $(0.0576)$ & $(0.0553)$ \\
\hline income $\$ 50-75 \mathrm{k}$ & $0.352 * * *$ & $0.251 * * *$ & $-0.270 * * *$ & $-0.144 * * *$ \\
\hline & $(0.0598)$ & $(0.0593)$ & $(0.0570)$ & $(0.0547)$ \\
\hline income $\$ 75-100 \mathrm{k}$ & $0.423 * * *$ & $0.416 * * *$ & $-0.431 * * *$ & -0.103 \\
\hline & $(0.0688)$ & $(0.0683)$ & $(0.0656)$ & $(0.0630)$ \\
\hline income $\$ 100-150 \mathrm{k}$ & $0.399 * * *$ & $0.446 * * *$ & $-0.491 * * *$ & -0.0939 \\
\hline & $(0.0710)$ & $(0.0704)$ & $(0.0677)$ & $(0.0649)$ \\
\hline income $>\$ 150 \mathrm{k}$ & $0.464 * * *$ & $0.515^{* * *}$ & $-0.619 * * *$ & -0.105 \\
\hline & $(0.0775)$ & $(0.0768)$ & $(0.0739)$ & $(0.0709)$ \\
\hline single & -0.0244 & 0.0514 & -0.0614 & 0.00332 \\
\hline & $(0.0436)$ & $(0.0432)$ & $(0.0416)$ & $(0.0399)$ \\
\hline separated & 0.0119 & $-0.0834 *$ & -0.0134 & -0.0331 \\
\hline & $(0.0455)$ & $(0.0452)$ & $(0.0434)$ & $(0.0417)$ \\
\hline widow & $0.174 *$ & 0.0392 & -0.0680 & $-0.161 * *$ \\
\hline & $(0.0895)$ & $(0.0888)$ & $(0.0854)$ & $(0.0819)$ \\
\hline income shock & $0.0853 * * *$ & $-0.0679 * *$ & $0.224 * * *$ & $0.0667 * *$ \\
\hline & $(0.0309)$ & $(0.0306)$ & $(0.0294)$ & $(0.0282)$ \\
\hline one kid & -0.0135 & 0.0104 & 0.0376 & $0.0725^{*}$ \\
\hline & $(0.0424)$ & $(0.0420)$ & $(0.0404)$ & $(0.0388)$ \\
\hline two kids & -0.0233 & -0.00733 & 0.0623 & 0.0502 \\
\hline & $(0.0409)$ & $(0.0406)$ & $(0.0390)$ & $(0.0374)$ \\
\hline three kids & -0.0790 & -0.0844 & 0.0517 & 0.0149 \\
\hline & $(0.0530)$ & $(0.0526)$ & $(0.0505)$ & $(0.0485)$ \\
\hline four or more kids & -0.0676 & -0.0610 & $0.254 * * *$ & $0.0983^{*}$ \\
\hline & $(0.0638)$ & $(0.0633)$ & $(0.0608)$ & $(0.0584)$ \\
\hline self-employed & -0.0701 & 0.0278 & 0.0332 & 0.00972 \\
\hline & $(0.0450)$ & $(0.0446)$ & $(0.0429)$ & $(0.0412)$ \\
\hline unemployed & 0.0397 & 0.0343 & -0.00295 & 0.0746 \\
\hline & $(0.0562)$ & $(0.0558)$ & $(0.0536)$ & $(0.0515)$ \\
\hline retired & -0.0119 & $0.153 * *$ & $-0.123^{*}$ & 0.00571 \\
\hline & $(0.0668)$ & $(0.0663)$ & $(0.0637)$ & $(0.0611)$ \\
\hline Constant & -0.218 & 0.0985 & $0.569 * *$ & $0.716 * * *$ \\
\hline & $(0.255)$ & $(0.253)$ & $(0.243)$ & $(0.233)$ \\
\hline Observations & 1,042 & 1,042 & 1,042 & 1,042 \\
\hline R-squared & 0.226 & 0.239 & 0.297 & 0.140 \\
\hline lard errors in $n$ & es & & & \\
\hline
\end{tabular}




\begin{tabular}{|c|c|c|c|c|}
\hline \multicolumn{5}{|c|}{ TABLE 5: Financial capability and self-assessed financial literacy (ages 25-65) } \\
\hline Variables: & $\begin{array}{l}\text { Retirement } \\
\text { planning }\end{array}$ & Emergency fund & $\begin{array}{l}\text { Having difficulty } \\
\text { with bills }\end{array}$ & $\begin{array}{l}\text { Using high-cost } \\
\text { borrowing }\end{array}$ \\
\hline Self-assessment & $0.0457 * * *$ & $0.0639 * * *$ & $-0.0468 * * *$ & 0.00127 \\
\hline & $(0.0100)$ & $(0.00975)$ & $(0.00950)$ & $(0.00922)$ \\
\hline age & 0.00700 & 0.00226 & 0.00229 & -0.00902 \\
\hline & $(0.0116)$ & $(0.0113)$ & $(0.0110)$ & $(0.0107)$ \\
\hline age squared & $-4.07 e-05$ & $1.08 \mathrm{e}-05$ & $-7.95 e-06$ & $2.22 \mathrm{e}-05$ \\
\hline & $(0.000132)$ & $(0.000129)$ & $(0.000125)$ & $(0.000122)$ \\
\hline female & -0.0286 & -0.0394 & 0.0267 & 0.0204 \\
\hline & $(0.0287)$ & $(0.0279)$ & $(0.0272)$ & $(0.0263)$ \\
\hline African-American & 0.0198 & $-0.125 * * *$ & 0.0638 & $0.0915 * *$ \\
\hline & $(0.0476)$ & $(0.0463)$ & $(0.0451)$ & $(0.0438)$ \\
\hline Hispanic & -0.0687 & -0.0416 & -0.0259 & $-0.0917 * *$ \\
\hline & $(0.0464)$ & $(0.0451)$ & $(0.0440)$ & $(0.0427)$ \\
\hline Asian & $-0.137 *$ & 0.0528 & -0.0740 & -0.0939 \\
\hline & $(0.0737)$ & $(0.0717)$ & $(0.0698)$ & $(0.0677)$ \\
\hline Other race & 0.0659 & -0.0887 & 0.0566 & -0.0397 \\
\hline & $(0.103)$ & $(0.100)$ & $(0.0978)$ & $(0.0949)$ \\
\hline high school & 0.0475 & 0.0622 & -0.0343 & $-0.104 * *$ \\
\hline & $(0.0532)$ & $(0.0518)$ & $(0.0504)$ & $(0.0489)$ \\
\hline some college & $0.116 * *$ & 0.0534 & -0.0218 & -0.0673 \\
\hline & $(0.0552)$ & $(0.0537)$ & $(0.0523)$ & $(0.0508)$ \\
\hline college & $0.212 * * *$ & $0.139 * *$ & -0.0663 & $-0.145^{* * *}$ \\
\hline & $(0.0588)$ & $(0.0572)$ & $(0.0557)$ & $(0.0540)$ \\
\hline post graduate & $0.231 * * *$ & $0.204 * * *$ & -0.0905 & $-0.165 * * *$ \\
\hline & $(0.0680)$ & $(0.0662)$ & $(0.0644)$ & $(0.0625)$ \\
\hline income $\$ 15-25 k$ & 0.0569 & -0.00858 & 0.0735 & $0.0950 *$ \\
\hline & $(0.0604)$ & $(0.0588)$ & $(0.0572)$ & $(0.0556)$ \\
\hline income $\$ 25-35 k$ & 0.0851 & 0.0975 & $-0.121 *$ & 0.0206 \\
\hline & $(0.0657)$ & $(0.0639)$ & $(0.0622)$ & $(0.0604)$ \\
\hline income $\$ 35-50 \mathrm{k}$ & $0.192 * * *$ & $0.242 * * *$ & $-0.184 * * *$ & -0.0683 \\
\hline & $(0.0606)$ & $(0.0590)$ & $(0.0575)$ & $(0.0558)$ \\
\hline income $\$ 50-75 \mathrm{k}$ & $0.339 * * *$ & $0.202 * * *$ & $-0.231 * * *$ & $-0.162 * * *$ \\
\hline & $(0.0597)$ & $(0.0581)$ & $(0.0565)$ & $(0.0549)$ \\
\hline income $\$ 75-100 \mathrm{k}$ & $0.393 * * *$ & $0.351 * * *$ & $-0.375 * * *$ & $-0.118 *$ \\
\hline & $(0.0692)$ & $(0.0674)$ & $(0.0656)$ & $(0.0636)$ \\
\hline income $\$ 100-150 \mathrm{k}$ & $0.390 * * *$ & $0.394 * * *$ & $-0.454 * * *$ & $-0.118^{*}$ \\
\hline & $(0.0705)$ & $(0.0686)$ & $(0.0668)$ & $(0.0648)$ \\
\hline income $>\$ 150 \mathrm{k}$ & $0.445^{* * *}$ & $0.457 * * *$ & $-0.576 * * *$ & $-0.126^{*}$ \\
\hline & $(0.0775)$ & $(0.0754)$ & $(0.0734)$ & $(0.0712)$ \\
\hline single & -0.0335 & 0.0357 & -0.0526 & 0.00639 \\
\hline & $(0.0436)$ & $(0.0424)$ & $(0.0413)$ & $(0.0401)$ \\
\hline separated & 0.00584 & $-0.0927 * *$ & 0.00172 & -0.0377 \\
\hline & $(0.0455)$ & $(0.0442)$ & $(0.0431)$ & $(0.0418)$ \\
\hline widow & 0.142 & -0.00104 & -0.0278 & $-0.163 * *$ \\
\hline & $(0.0895)$ & $(0.0871)$ & $(0.0848)$ & $(0.0823)$ \\
\hline income shock & $0.0940 * * *$ & $-0.0511^{*}$ & $0.215^{* * *}$ & $0.0653^{* *}$ \\
\hline & $(0.0309)$ & $(0.0300)$ & $(0.0292)$ & $(0.0284)$ \\
\hline one kid & -0.0162 & 0.00778 & 0.0398 & $0.0764 * *$ \\
\hline & $(0.0422)$ & $(0.0411)$ & $(0.0400)$ & $(0.0388)$ \\
\hline two kids & -0.0215 & -0.00673 & 0.0580 & 0.0547 \\
\hline & $(0.0409)$ & $(0.0398)$ & $(0.0387)$ & $(0.0376)$ \\
\hline three kids & $-0.100^{*}$ & $-0.117^{*} *$ & 0.0756 & 0.0182 \\
\hline & $(0.0530)$ & $(0.0516)$ & $(0.0502)$ & $(0.0487)$ \\
\hline four or more kids & -0.0742 & -0.0589 & $0.255^{* * *}$ & $0.106 *$ \\
\hline & $(0.0635)$ & $(0.0618)$ & $(0.0602)$ & $(0.0584)$ \\
\hline self-employed & $-0.0837 *$ & 0.0153 & 0.0390 & 0.00843 \\
\hline & $(0.0448)$ & $(0.0435)$ & $(0.0424)$ & $(0.0412)$ \\
\hline unemployed & 0.0283 & 0.0228 & 0.0121 & 0.0783 \\
\hline & $(0.0560)$ & $(0.0545)$ & $(0.0531)$ & $(0.0515)$ \\
\hline retired & -0.0178 & $0.139 * *$ & $-0.122^{*}$ & 0.00966 \\
\hline & $(0.0668)$ & $(0.0650)$ & $(0.0633)$ & $(0.0615)$ \\
\hline Constant & -0.312 & -0.178 & $0.782 * * *$ & $0.705^{* * *}$ \\
\hline & $(0.253)$ & $(0.246)$ & $(0.240)$ & $(0.233)$ \\
\hline Observations & 1,038 & 1,038 & 1,038 & 1,038 \\
\hline R-squared & 0.231 & 0.273 & 0.311 & 0.138 \\
\hline lard errors in & $\begin{array}{l}\text { es } \\
<0.1\end{array}$ & & & \\
\hline
\end{tabular}




\begin{tabular}{|c|c|c|c|c|c|c|c|c|c|c|c|}
\hline \multicolumn{12}{|c|}{ TABLE 6: Using the Social Security statements by demographics } \\
\hline & & \multicolumn{3}{|c|}{$\underline{\text { Income }}$} & \multicolumn{4}{|c|}{$\underline{\text { Age }}$} & \multicolumn{3}{|c|}{ Race } \\
\hline & $\underline{\text { Total }}$ & $<\$ 25 \mathrm{~K}$ & $\begin{array}{l}\$ 25- \\
75 K\end{array}$ & $>\$ 75 \mathrm{~K}$ & $18-34$ & $35-54$ & $55-70$ & $71+$ & White & $\begin{array}{l}\text { African- } \\
\text { American }\end{array}$ & Hispanic \\
\hline $\begin{array}{l}\text { Received } \\
\text { statement }\end{array}$ & $65 \%$ & $37 \%$ & $74 \%$ & $86 \%$ & $43 \%$ & $81 \%$ & $77 \%$ & $41 \%$ & $73 \%$ & $56 \%$ & $44 \%$ \\
\hline $\begin{array}{l}\text { Used statement } \\
\text { for retirement }\end{array}$ & $21 \%$ & $24 \%$ & $21 \%$ & $18 \%$ & $12 \%$ & $29 \%$ & $36 \%$ & $53 \%$ & $18 \%$ & $31 \%$ & $25 \%$ \\
\hline $\begin{array}{l}\text { Used } \\
\text { statement for } \\
\text { benefits }\end{array}$ & $25 \%$ & $30 \%$ & $27 \%$ & $21 \%$ & $20 \%$ & $23 \%$ & $52 \%$ & $39 \%$ & $24 \%$ & $35 \%$ & $24 \%$ \\
\hline $\begin{array}{l}\text { Note: This table rep } \\
\text { row reports the prc } \\
\text { decide or adjust th } \\
\text { adjust the decision }\end{array}$ & $\begin{array}{l}\text { is the } \\
\text { rtion } \\
\text { ecision }\end{array}$ & $\begin{array}{l}\text { of the } 5 \\
\text { esponde } \\
\text { nen to } s\end{array}$ & $\begin{array}{l}\text { I Sect } \\
\text { who h } \\
\text { worki } \\
\text { ial se }\end{array}$ & $\begin{array}{l}\text { statemen } \\
\text { received } \\
\text { ad the th }\end{array}$ & $\begin{array}{l}\text { dminis } \\
\text { e state } \\
\text { report }\end{array}$ & $\begin{array}{l}d \text { by th } \\
\text { t, the s } \\
\text { e propc }\end{array}$ & $\begin{array}{l}\text { cial Se } \\
\mathrm{d} \text { rep } \\
\text { n of re }\end{array}$ & $\begin{array}{l}\text { Adm } \\
\text { e pro } \\
\text { dents }\end{array}$ & $\begin{array}{l}\text { tration } \\
\text { tion wh } \\
\text { o have } 4\end{array}$ & $\begin{array}{l}\text { nographic } \\
\text { e used the } \\
\text { he stateme }\end{array}$ & $\begin{array}{l}\text { up. The firs } \\
\text { ement to } \\
\text { o decide or }\end{array}$ \\
\hline
\end{tabular}




\begin{tabular}{|c|c|c|c|c|}
\hline \multicolumn{5}{|c|}{ TABLE 7: Using the Social Security statements (ages 25-65) } \\
\hline Variables: & $\begin{array}{c}\text { Retirement } \\
\text { decision }\end{array}$ & Claim SSA benefits & $\begin{array}{c}\text { Retirement } \\
\text { decision }\end{array}$ & Claim SSA benefits \\
\hline basic literacy & $\begin{array}{c}-0.0141 \\
(0.0689)\end{array}$ & $\begin{array}{c}0.0481 \\
(0.0712)\end{array}$ & - & - \\
\hline high literacy & $\begin{array}{c}0.0212 \\
(0.0331)\end{array}$ & $\begin{array}{c}0.0536 \\
(0.0341)\end{array}$ & - & - \\
\hline Self-assessment & - & - & $\begin{array}{c}0.0226 * * \\
-0.0108\end{array}$ & $\begin{array}{l}0.0216 * \\
-0.0112\end{array}$ \\
\hline age & $-0.0204 *$ & -0.0141 & -0.0197 & -0.0132 \\
\hline & $(0.0123)$ & $(0.0127)$ & -0.0123 & -0.0127 \\
\hline age squared & $0.000324 * *$ & $0.000295^{* *}$ & $0.000315^{* *}$ & $0.000284 * *$ \\
\hline & $(0.000139)$ & $(0.000144)$ & -0.000139 & -0.000144 \\
\hline female & -0.0165 & -0.0105 & -0.0176 & -0.0168 \\
\hline & $(0.0297)$ & $(0.0307)$ & -0.0294 & -0.0304 \\
\hline African-American & $0.119 * *$ & 0.0849 & $0.117 * *$ & 0.0832 \\
\hline & $(0.0506)$ & $(0.0522)$ & -0.0502 & -0.052 \\
\hline Hispanic & 0.0581 & 0.00993 & 0.0534 & -0.000824 \\
\hline & $(0.0500)$ & $(0.0516)$ & -0.0496 & -0.0514 \\
\hline Asian & -0.0121 & -0.00680 & -0.0101 & -0.00571 \\
\hline & $(0.0738)$ & $(0.0762)$ & -0.0735 & -0.0761 \\
\hline Other race & 0.155 & 0.168 & 0.151 & 0.163 \\
\hline & $(0.108)$ & $(0.112)$ & -0.108 & -0.112 \\
\hline high school & -0.0305 & -0.0803 & -0.0357 & -0.0852 \\
\hline & $(0.0582)$ & $(0.0601)$ & -0.0578 & -0.0598 \\
\hline some college & -0.0825 & $-0.110^{*}$ & -0.0851 & $-0.105^{*}$ \\
\hline & $(0.0596)$ & $(0.0615)$ & -0.0591 & -0.0612 \\
\hline college & -0.0198 & -0.0902 & -0.0241 & -0.0871 \\
\hline & $(0.0621)$ & $(0.0641)$ & -0.0617 & -0.0639 \\
\hline post graduate & -0.0549 & -0.0845 & -0.0553 & -0.0741 \\
\hline & $(0.0694)$ & $(0.0716)$ & -0.0688 & -0.0712 \\
\hline income $\$ 15-25 k$ & 0.0130 & 0.0611 & -0.00704 & 0.0482 \\
\hline & $(0.0747)$ & $(0.0771)$ & -0.0747 & -0.0773 \\
\hline income $\$ 25-35 k$ & 0.0313 & 0.0114 & 0.023 & 0.0138 \\
\hline & $(0.0800)$ & $(0.0826)$ & -0.0795 & -0.0822 \\
\hline income $\$ 35-50 k$ & 0.0391 & 0.0279 & 0.0249 & 0.0238 \\
\hline & $(0.0750)$ & $(0.0774)$ & -0.0749 & -0.0775 \\
\hline income $\$ 50-75 \mathrm{k}$ & 0.0674 & 0.0997 & 0.0478 & 0.096 \\
\hline & $(0.0735)$ & $(0.0759)$ & -0.0735 & -0.076 \\
\hline income $\$ 75-100 \mathrm{k}$ & 0.0544 & 0.0365 & 0.0308 & 0.0277 \\
\hline & $(0.0810)$ & $(0.0836)$ & -0.0812 & -0.084 \\
\hline income $\$ 100-150 k$ & 0.0301 & 0.00308 & 0.0129 & 0.00435 \\
\hline & $(0.0827)$ & $(0.0853)$ & -0.0822 & -0.0851 \\
\hline income $>\$ 150 k$ & -0.0234 & -0.0507 & -0.0437 & -0.0556 \\
\hline & $(0.0883)$ & $(0.0911)$ & -0.0882 & -0.0913 \\
\hline single & $0.0823 *$ & $0.0869 *$ & $0.0781 *$ & $0.0860 *$ \\
\hline & $(0.0466)$ & $(0.0481)$ & -0.0465 & -0.0481 \\
\hline separated & $0.0966 * *$ & 0.0548 & $0.0936 *$ & 0.051 \\
\hline & $(0.0483)$ & $(0.0499)$ & -0.0481 & -0.0498 \\
\hline widow & -0.158 & -0.0712 & $-0.179 *$ & -0.091 \\
\hline & $(0.100)$ & $(0.103)$ & -0.0999 & -0.103 \\
\hline income shock & 0.00773 & $0.0658 * *$ & 0.0126 & $0.0701 * *$ \\
\hline & $(0.0314)$ & $(0.0324)$ & -0.0314 & -0.0324 \\
\hline one kid & -0.0623 & -0.0425 & -0.0617 & -0.0438 \\
\hline & $(0.0418)$ & $(0.0432)$ & -0.0417 & -0.0431 \\
\hline two kids & -0.0571 & $-0.0985 * *$ & -0.0538 & $-0.0959 * *$ \\
\hline & $(0.0414)$ & $(0.0427)$ & -0.0413 & -0.0427 \\
\hline three kids & -0.0449 & $-0.0900 *$ & -0.0548 & $-0.0995^{*}$ \\
\hline & $(0.0528)$ & $(0.0545)$ & -0.0527 & -0.0546 \\
\hline four or more kids & -0.0295 & -0.0883 & -0.027 & -0.0883 \\
\hline out ol mivie kius & $(0.0640)$ & $(0.0660)$ & -0.0638 & -0.066 \\
\hline self-employed & -0.0720 & -0.0443 & $-0.0746 *$ & -0.052 \\
\hline & $(0.0455)$ & $(0.0469)$ & -0.0449 & -0.0464 \\
\hline unemployed & -0.0444 & -0.0440 & -0.0439 & -0.0449 \\
\hline & $(0.0594)$ & $(0.0613)$ & -0.0591 & -0.0612 \\
\hline Constant & 0.453 & 0.235 & 0.347 & 0.192 \\
\hline & $(0.276)$ & $(0.285)$ & -0.273 & -0.282 \\
\hline Observations & 764 & 764 & 764 & 764 \\
\hline R-squared & 0.101 & 0.164 & 0.106 & 0.164 \\
\hline$d \in$ & ses & & & \\
\hline
\end{tabular}




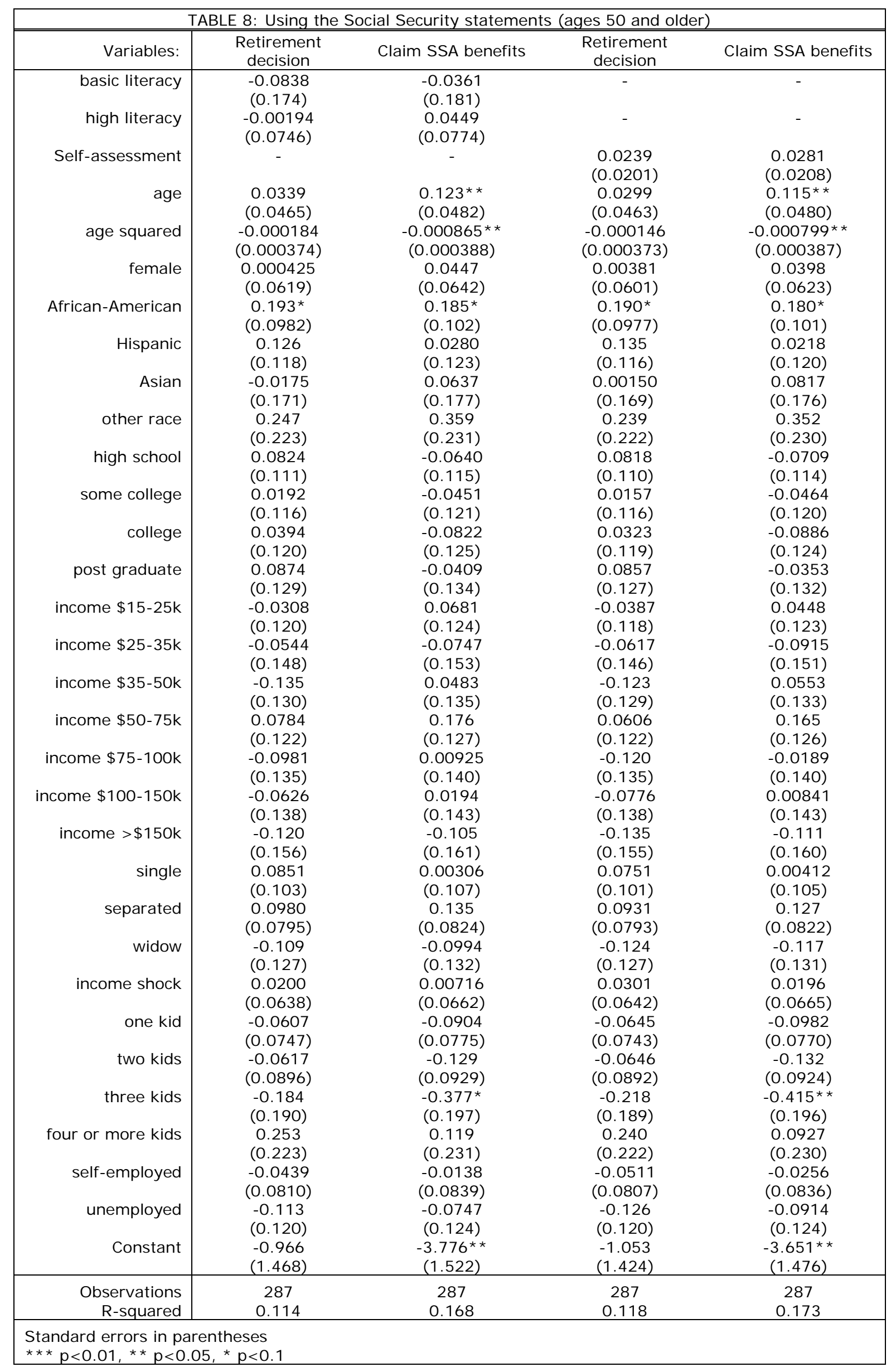


